\title{
Evaluation of chemical compositions of Citrulus lanatus seed and Cocos nucifera stem bark
}

\author{
"Damilola Alex Omoboyowa', Glory Otuchristian', Garba Jeremiah Danladi', Chintua Ephraim \\ Igara $^{2}$, Kerian Chigozie Ngobidi $^{1}$, Martin Umoh Okon ${ }^{1}$ and Flourence Amaka Agbo ${ }^{1}$ \\ *,1Biochemistry Research Unit, ${ }^{2}$ Chemistry Research Unit, Department of Science Laboratory Technology, Akanu Ibiam \\ Federal Polytechnic, Unwana, Afikpo, Ebonyi State, Nigeria \\ Conresponding Author Email: damlexb@yahoo.com
}

\begin{abstract}
The seed of Citrulus lanatus and Cocos nucifera stem bark were analyzed for their phytochemical, proximate, nutrient and anti-nutrient compositions. The results obtained from the analysis of both plants were compared. The result reveals that both plants contain substantial amount of saponnins, tannins, flavonoids, terpenoids and phenol. The concentration of alkaloids and steroids present in the C. lanatus seed were significantly $(p<0.0 .05)$ higher compared with the level observed in $C$. nucifera stem bark. There was generally low percentage proximate fractions of $C$. lanatus seeds in terms ash and fibre and low percentage fractions of protein, ash, fats and fibre were observed in the $C$. nucifera stem bark. Protein and fats composition of $C$. lanatus seed were observed to be significantly $(P<0.05)$ higher compared with the compositions present in $C$. nucifera stem bark Iron was the most abundant micro element present ranging from $4.089 \mu \mathrm{g} / \mathrm{g}$ in $C$. lanatus seed to $3.66 \mu \mathrm{g} / \mathrm{g}$ in $C$. nucifera stem bark. This was followed by zinc; the values of magnesium were very traced in both plants. Results of analysis of $C$. lanatus seed and $C$. nucifera stem bark showed that the plants are rich in some vitamins such as vitamin $A, E$ and $C$ which were observed to be abundant while low concentration of vitamin $B_{1}, B_{2}$ and $B_{3}$ were observed in both plants. The anti-nutrient analysis of $C$. lanatus seed and $C$. nucifera stem bark revealed low level of phytate, oxalate, hemaglutinin and trypsin inhibitor ranging from $0.677 \mathrm{mg} / 100 \mathrm{~g}$ to $2.370 \mathrm{mg} / 100 \mathrm{~g}, 0.082 \mathrm{mg} / 100 \mathrm{~g}$ to $0.97 \mathrm{mg} / 100 \mathrm{~g}, 0.549 \%$ to $0.690 \%$ and $0.456 \mathrm{mg} / 100 \mathrm{~g}$ to $0.550 \mathrm{mg} / 100$ $\mathrm{g}$ respectively. This study has shown that $C$. lanatus seed and $C$. nucifera stem bark are good source of phytochemicals that are biologically important, thus they can be potential sources of useful drugs in the management of some ailments.
\end{abstract}

Keywords: Phytochemicals; Proximate; Nutrients; Anti-nutrients

\section{INTRODUCTION}

Plants and their derivatives play key role in world health and have long been known to possess biological activity. Thirty percent of all modern drugs were derived from plants (Riaz et al., 2010; Omoboyowa et al., 2013). According to the World Health Organization, about $80 \%$ of the world's population relies essentially on plants for primary health care (Omoboyowa et al., 2013). There is growing interest in exploiting plants for medicinal purposes especially in Africa (Adeniyi et al., 2012). Citrulus lanatus (watermelon) contains significant amount of citrulline and after consumption of several kilograms an elevated concentration was measured in blood plasma (Mendal et al., 2005). Its single brown seed is high in certain fat and oil (oleic and arachidonic acid) valuable to industry, used in cooking and manufacturing of soap (Collins et al., 2007). Watermelon flesh is rich sources of citrulline, which can be metabolized to arginine. This amino acid is a substrate for the synthesis of nitric oxide and it plays a role in cardiovascular and immune system (Collins et al., 2007). Cocos nucifera commonly known as coconut palm is a member of the family arecaceae (palm family). It is found throughout the tropic and subtropical 
area, it is known for its great versatility as a result of many uses of its various parts. The seed provides oil for frying, cooking and for making margarine, the coconut water contains sugar, dietary fibre, proteins, antioxidants, vitamins and minerals (Ravi, 2009), medicinally, nhexane fraction of coconut peel contains novel anticancer compounds, young coconut juice has estrogenic-like characteristics, it can be used as intravenous hydration fluid, the tea from the husk fibre is used to treat severe inflammatory disorder (Sarian, 2010). This present study was design to evaluate the secondary metabolites, proximate, nutrients and anti-nutrient composition of Citrulus lanatus seed commonly discarded after consumption of the fruits and Cocos nucifera stem bark commonly used in alternative herbal medicine in Nigeria, in a view to highlight their pharmacological roles in traditional medicine.

\section{MATERIALS AND METHODS}

\section{Plant material}

The fresh Citrulus lanatus (watermelon) fruits used for this study were purchased from Eke market, Afikpo North Local Government Area of Ebonyi State, Nigeria. The seeds were removed from the pulp with the aid of a sterilized knife, the seeds were cleaned, air dried and carefully ground into a coase form by the use of a mechanical blender. Coconut palm (Cocos nucifera) stem bark used for this study was collected from Ogbu Edda, Afrikpo South Local Government Area of Ebonyi State, Nigeria. It was harvested with a clean cutlass, air dried at room temperature for three (3) weeks, ground with a mechanical blender into coarse form..

\section{Preparation of fat free sample}

Two grams $(2 \mathrm{~g})$ of the samples were defatted with 100 $\mathrm{ml}$ of diethyl ether using a soxhlet apparatus for 2 hours.

\section{Phytochemical Analysis}

\section{Phytochemical analysis}

Chemical tests were carried out on the samples for the quantitative determination of phytochemical constituents.

\section{Alkaloid determination}

The alkaloid content was determined gravimetrically. Five grams of the sample were weighed into a $250 \mathrm{ml}$ beaker and $200 \mathrm{ml}$ of $20 \%$ acetic acid in ethanol was added and covered to stand for $4 \mathrm{~h}$. This was filtered and the extract was concentrated using a water-bath to one-quarter of the original volume. Concentrated ammonium hydroxide was added drop wise to the extract until the precipitation was complete. The whole solution was allowed to settle and the precipitate was collected by filtration using Whatman filter paper No. $4(125 \mathrm{~mm})$ and weighed (Obadoni and Ochuko, 2001).

\section{Saponin determination}

Saponin content was determined using the method described by Obadoni and Ochuko, (2001). Twenty grams $(20 \mathrm{~g})$ of each ground samples were dispersed in $200 \mathrm{ml}$ of $20 \%$ ethanol. The suspension was heated over a hot water bath for $4 \mathrm{~h}$ with continuous stirring at about $55^{\circ} \mathrm{C}$. The mixture was filtered and the residue reextracted with another $200 \mathrm{ml}$ of $20 \%$ ethanol. The combined extracts were reduced to $40 \mathrm{ml}$ over water bath at about $90^{\circ} \mathrm{C}$. The concentrate was transferred into a $250 \mathrm{ml}$ separator funnel and $20 \mathrm{ml}$ of diethyl ether was added and shaken vigorously. The aqueous layer was recovered while the ether layer was discarded. The purification process was repeated. $60 \mathrm{ml}$ of n-butanol was added. The mixture of $\mathrm{n}$-butanol and extracts was washed twice with $10 \mathrm{ml}$ of $5 \%$ aqueous sodium chloride. The remaining solution was heated in a water bath at about $90^{\circ} \mathrm{C}$. The samples were dried in an oven at $100^{\circ} \mathrm{C}$ until a constant weight was obtained. The saponin content was calculated in percentage (Obadoni and Ochuko, 2001).

\section{Tannin determination}

Tannin content was determined going by the method described by Van-Burden and Robinson (1981). Five hundred miligrams of the sample was weighed into 100 $\mathrm{ml}$ plastic bottle. $50 \mathrm{ml}$ of distilled water was added and shaken for $1 \mathrm{~h}$ in a mechanical shaker. This was filtered into a $50 \mathrm{ml}$ volumetric flask and made up to the mark. Then $5 \mathrm{ml}$ of the filtrate was pipette out into a tube and mixed with $3 \mathrm{ml}$ of $0.1 \mathrm{M} \mathrm{FeCl}_{3}$ in $0.1 \mathrm{~N} \mathrm{HCl}$ and $0.008 \mathrm{M}$ potassium ferrocyanide. The absorbance was measured in a spectrophotometer at $120 \mathrm{~nm}$ wavelength, within 10 min. A blank sample was prepared and the colour also developed and read at the same wavelength. A standard was prepared using tannin acid to get $100 \mathrm{ppm}$ and measured (Van-Burden and Robinson, 1981).

\section{Flavonoid determination}

Flavonoid content was determined using the method described by Boham and Kocipai (1994). Ten grams of the ground samples were extracted repeatedly with 300 $\mathrm{ml}$ of methanol:water $(80: 20)$ at room temperature. The whole solution was filtered through Whatman filter paper No. $42(125 \mathrm{~mm})$. The filtrate was later transferred into a 
crucible and evaporated to dryness over a water bath and weighed (Boham and Kocipai, 1994).

\section{Determination of total phenols}

Total phenols were determined using the method described by Obadoni and Ochuko (2001). For the extraction of phenolic component, the fat free sample was boiled with $50 \mathrm{ml}$ of ether for $15 \mathrm{~min} .5 \mathrm{ml}$ of the extract was pipette into a $50 \mathrm{ml}$ volumetric flask, then 10 $\mathrm{ml}$ of distilled water was added. $2 \mathrm{ml}$ of ammonium hydroxide solution and $5 \mathrm{ml}$ of concentrated amyl alcohol were also added. The samples were made up to mark and left to react for $30 \mathrm{~min}$ for colour development. The absorbance of the solution was read using a spectrophotometer at $505 \mathrm{~nm}$ wavelengths (Obadoni and Ochuko, 2001).

\section{Cyanogenic glycoside determination}

The method used was alkaline picrate method of Onwuka, (2005). $5 \mathrm{~g}$ of each sample A. and B were added $50 \mathrm{~mL}$ distilled water in a conical flask and allowed to stand overnight. To $1 \mathrm{~mL}$ of the sample filtrate in a corked test tube $4 \mathrm{~mL}$ of alkaline picrate was added and incubated in a water bath for $5 \mathrm{~min}$. The absorbance of the samples were taken at $490 \mathrm{~mm}$ and that of a blank containing $1 \mathrm{~mL}$ distilled water and $4 \mathrm{~mL}$ alkaline picrate solution before the preparation of cyanide standard curve but there was no colour change in any of the corked test tube containing he sample $A$ and $B$ which is the indication of absence of cyanide in the sample i.e., colour changed from yellow to reddish brown after incubation for $5 \mathrm{~min}$ in a water bath (Railes, 1992).

\section{Proximate Composition Analysis}

This was carried out according to the method of AOAC (1990)

\section{Moisture Content Determination}

Two grams of each of the sample was weighed into dried weighed crucible. The samples was put into a moisture extraction oven at $105^{\circ} \mathrm{C}$ and heated for 3 hours. The dried samples was put into desiccators, allowed to cool and reweighed. The process was reported until constant weight was obtained the difference in weight was calculated as a percentage of the original sample

$$
\text { Percentage moisture }=\frac{\mathrm{W}_{2}-\mathrm{W}_{1}}{\mathrm{~W}_{2}-\mathrm{W}_{3}} \times \frac{100}{1}
$$

Where

$\mathrm{W}_{1} \quad=$ Initial weight of empty dish

$\mathrm{W}_{2} \quad=$ Weight of dish + Un-dried sample

$\mathrm{W}_{3}=$ Weight of dish + dried sample

\section{Ash Content Determination}

Two grams of each of the samples was weighed into crucible, heated in a moisture extraction oven for 3hour at $100^{\circ} \mathrm{C}$ before being transferred into a muffle furnace at $550^{\circ} \mathrm{C}$ until it turned white and free of carbon. The sample was then removed from the furnace, cooled in a desicator to a room temperature and reweighed immediately. The weight of the residual ash was then calculated as

Ash Content

Percentage Ash

$$
=\frac{\text { Weight of Ash }}{\times \quad \frac{100}{1}}
$$

\section{Crude Protein Determination}

The micro kjeldahl method described by A.O.A.C (1990) was used. Two grams of each of the sample was mixed with $10 \mathrm{ml}$ of concentrated $\mathrm{H}_{2} \mathrm{SO}_{4}$ in a heating tube. One table of selenium catalysts was added to the tube and mixture heated inside a fume cupboard. The digest was transferred into distilled water. Ten millimeter portion of the digest mixed with equal volume of $45 \% \mathrm{NaOH}$. Solution and poured into a kjeldahl distillation apparatus. The mixture was distilled and the distilled collected into $4 \%$ boric acid solution containing 3 drops of methyl red indicator. A total of $50 \mathrm{ml}$ distillate was collected and titrated as well. The sample was duplicated and the average value taken. The nitrogen content was calculated and multiplied with 6.25 to obtain the crude protein content. This is given as percentage Nitrogen

$$
=\frac{(100 \times \mathrm{N} \times 14 \times \mathrm{VF}) \mathrm{T}}{100 \times \mathrm{Va}}
$$

Where

$\mathrm{N} \quad=$ Normality of the titrate $(0.1 \mathrm{~N})$

$\mathrm{VF} \quad=$ Total volume of the digest $=100 \mathrm{ml}$

$\mathrm{T} \quad=$ Titre value

Va = Aliquot volume distilled

\section{Crude Fiber Determination}

Two grams $(2 \mathrm{~g})$ sample and $1 \mathrm{~g}$ asbestos were put into $200 \mathrm{ml}$ of $1.25 \%$ of $\mathrm{H}_{2} \mathrm{SO}_{4}$ and boiled for 30 minutes. The solution and content then poured into Buchner funnel equipped with muslin cloth and secured with elastic band. This was allowed to filter and residue was then put into $200 \mathrm{ml}$ boiled $\mathrm{NaOH}$ and boiling continued for 30 minutes, then transferred to the Buchner funnel and filtered. It was then washed twice with alcohol. The material obtained washed thrice with petroleum ether. The residue obtained was put in a clean dry crucible and dried in the moisture extraction oven to a constant weight. The dried crucible was removed, cooled and weighed. Then, difference of 
weight (i.e. loss in ignition) is recorded as crucible fiber and expressed in percentage crude fiber,

$$
=\frac{W_{1}}{W_{3}}-W_{2} \times \frac{100}{1}
$$

Where

$\mathrm{W}_{1} \quad=$ Weight of sample before incineration

$\mathrm{W}_{2} \quad=$ Weight of sample after incineration

$\mathrm{W}_{3} \quad=$ Weight of original sample

\section{Fat Content Determination}

Two grams of the sample was loosely wrapped with a filter paper and put into the thimble which was filled to a clean round bottom flask, which has been cleaned, dried and weighed. The flask contained $120 \mathrm{ml}$ of petroleum ether. The sample was heated with a heating mantle and allowed to reflux for 5 hours. The heating was then stopped and the thimbles with the spent samples kept and later weighed. The difference in weight was received as mass of fat and is expressed in percentage of the sample. The percentage oil content is percentage fat

$$
=\frac{W_{2}}{W_{3}}-W_{1} \times \frac{100}{1}
$$

Where

$\mathrm{W}_{1} \quad=$ Weight of the empty extraction flask

$\mathrm{W}_{2} \quad=$ Weight of the flask and oil extracted

$\mathrm{W}_{3} \quad=$ Weight of the sample

\section{Carbohydrate Content Determination}

The nitrogen free method described by A.O.A.C (1990) was used. The carbohydrate is calculated as weight by difference between 100 and the summation of other proximate parameters as

Nitrogen Free Extract (NFE) percentage

carbohydrate

$(\mathrm{NFE})=100-\left(\mathrm{M}+\mathrm{P}+\mathrm{F}_{1}+\mathrm{A}+\mathrm{F}_{2}\right)$

$$
\begin{array}{ll}
\text { Where } & \\
\mathrm{M} & =\text { moisture } \\
\mathrm{P} & =\text { protein } \\
\mathrm{F}_{1} & =\text { fat } \\
\mathrm{A} & =\text { ash } \\
\mathrm{F}_{2} & =\text { crude fiber. }
\end{array}
$$

\section{Nutrients analysis}

\section{Mineral Determination}

The major elements, comprising calcium, phosphorus, sodium, potassium, magnesium and trace elements (iron and zinc) were determined according to the method of Shahidi et al. (1999). The ground plant samples were sieved with a $2 \mathrm{~mm}$ rubber sieve and $2 \mathrm{~g}$ of each of the plant samples were weighed and subjected to dry ashing in a well-cleaned porcelain crucible at $550^{\circ} \mathrm{C}$ in a muffle furnace. The resultant ash was dissolved in $5 \mathrm{ml}$ of $\mathrm{HNO}_{3} / \mathrm{HCl} / \mathrm{H}_{2} \mathrm{O}(1: 2: 3)$ and heated gently on a hot plate until brown fumes disappeared. To the remaining material in each crucible, $5 \mathrm{ml}$ of deionized water was added and heated until a colourless solution was obtained. The mineral solution in each crucible was transferred into a $100 \mathrm{ml}$ volumetric flask by filtration through a whatman No 42 filter paper and the volume was made to the mark with deionized water. This solution was used for elemental analysis by atomic absorption spectrophotometer. A $10 \mathrm{~cm}$-long cell was used and concentration of each element in the sample was calculated on percentage of dry matter. Phosphorus content of the digest was determined colorimetrically according to the method described by Nahapetian and Bassiri (1975). To $0.5 \mathrm{ml}$ of the diluted digest, $4 \mathrm{ml}$ of demineralised water, $3 \mathrm{ml}$ of $0.75 \mathrm{M} \mathrm{H}_{2} \mathrm{SO}_{4}, 0.4 \mathrm{ml}$ of $10 \%$ $\left(\mathrm{NH}_{4}\right) 6 \mathrm{MO}_{7} \mathrm{O}_{24} .4 \mathrm{H}_{2} \mathrm{O}$ and $0.4 \mathrm{ml}$ of $2 \%(\mathrm{w} / \mathrm{v})$ ascorbic acid were added and mixed. The solution was allowed to stand for $20 \mathrm{~min}$ and absorbance readings were recorded at $660 \mathrm{~nm}$. The content of phosphorus in the extract was determined.

\section{Vitamin Analysis \\ Determination of ascorbic acid (Vitamin C)}

Vitamin C content was determined according to the method of Baraket et al. (1973). Five grams of the sample was weighed into an extraction tube and $100 \mathrm{ml}$ of EDTA/TCA (2:1) extracting solution were mixed and the mixture shaken for $30 \mathrm{~min}$. This was transferred into a centrifuge tube and centrifuged at $3000 \mathrm{rpm}$ for $20 \mathrm{~min}$. It was transferred into a $100 \mathrm{ml}$ volumetric flask and made up to $100 \mathrm{ml}$ mark with the extracting solution. $20 \mathrm{ml}$ of the extract was pipetted into the volumetric flask and $1 \%$ starch indicator was added. These were titrated with $20 \%$ $\mathrm{CuSO}_{4}$ solution to get a dark end point (Baraket et al., 1973).

\section{Determination of vitamin A}

One gram $(1 \mathrm{~g})$ of the sample was weighed and macerated with $20 \mathrm{mls}$ of petroleum ether. It was evaporated to dryness and $0.2 \mathrm{ml}$ of chloroform acetic anhydride was added and $2 \mathrm{mls}$ of TCA chloroform were added and the absorbance measured at $620 \mathrm{~nm}$. Then concentration of vitamin $A$ was extrapolated from the standard curve.

\section{Determination of vitamin E}

One gram $(1 \mathrm{~g})$ of the sample was weighed and macerated with $20 \mathrm{mls}$ of ethanol. One milliliter $(1 \mathrm{ml})$ of $0.2 \%$ ferric chloride in ethanol was added, then $1 \mathrm{ml}$ of $0.5 \%$ a, a-dipyridyl was also added, It was diluted to $5 \mathrm{mls}$ 
with distilled water and absorbance was measured at $520 \mathrm{~nm}$. Then concentration of Vitamin $E$ was extrapolated from the standard curve.

\section{Determination of niacin}

Niacin content was determined according to the method of Okwu and Josiah, (2006). Five grams of the sample was treated with $50 \mathrm{ml}$ of $1 \mathrm{~N}$ sulphuric acid and shaken for $30 \mathrm{~min}$. 3 drops of ammonia solution $(0.1 \mathrm{~N})$ were added to the sample and filtered. $10 \mathrm{ml}$ of the filtrate was pipetted into a $50 \mathrm{ml}$ volumetric flask and $5 \mathrm{ml}$ potassium cyanide was added. This was acidified with $5 \mathrm{ml}$ of 0.02 $\mathrm{N} \quad \mathrm{H}_{2} \mathrm{SO}_{4}$ and absorbance measured in the spectrophotometer at $470 \mathrm{~nm}$ wavelength (Okwu and Josiah, 2006).

\section{Determination of riboflavin}

Riboflavin content was determined according to the method of Okwu and Josiah, (2006). Five grams of the sample was extracted with $100 \mathrm{ml}$ of $50 \%$ ethanol solution and shaken for $1 \mathrm{~h}$. This was filtered into $100 \mathrm{ml}$ flask; $10 \mathrm{ml}$ of the extract was pipetted into $50 \mathrm{ml}$ volumetric flask. $10 \mathrm{ml}$ of $5 \%$ potassium permanganate and $10 \mathrm{ml}$ of $30 \% \mathrm{H}_{2} \mathrm{O}_{2}$ were added and allowed to stand over a hot water bath for about $30 \mathrm{~min}$. $2 \mathrm{ml}$ of $40 \%$ sodium sulphate was added. This was made up to $50 \mathrm{ml}$ mark with deionized water and the absorbance measured at $510 \mathrm{~nm}$ in a spectrophotometer (Okwu and Josiah, 2006).

\section{Determination of thiamine}

Thiamine content was determined according to the method of Okwu and Josiah, (2006). Five grams of the sample were homogenized with ethanolic sodium hydroxide $(50 \mathrm{ml})$. It was filtered into a $100 \mathrm{ml}$ flask. $10 \mathrm{ml}$ of the filtrate was pipetted and the colour developed by addition of $10 \mathrm{ml}$ potassium dichromate and read at 360 $\mathrm{nm}$. A blank was prepared and the colour also developed and read at the same wavelength (Okwu and Josiah, 2006).

\section{Anti-nutrients analysis}

\section{Oxalate determination}

The oxalate content of the samples was determined using titration method. $2 \mathrm{~g}$ of each sample $\mathrm{A}$ and $\mathrm{B}$ were placed in a $250 \mathrm{~mL}$ volumetric flask suspended in $190 \mathrm{~mL}$ distilled water. $10 \mathrm{ml} 6 \mathrm{MHCl}$ solution was added to each of the samples and the suspension digested at $100^{\circ} \mathrm{C}$ for 1h. The samples were then cooled and made up to 250 $\mathrm{mL}$ mark of the flask. The samples were filtered and duplicate portion of $125 \mathrm{~mL}$ of the filtrate were measured into beaker and four drops of methyl red indicator was added, followed by the addition of concentrated $\mathrm{NH}_{4} \mathrm{OH}$ solution (drop wise) until the solution changed from pink to yellow colour. Each portion was then heated to $90^{\circ} \mathrm{C}$, cooled and filtered to remove the precipitate containing ferrous ion. Each of the filtrate was again heated to $90^{\circ} \mathrm{C}$ and $10 \mathrm{~mL}$ of $5 \% \mathrm{CaCl}_{2}$ solution was added to each of the samples with stirring consistently. After cooling, the samples were left overnight. The solutions were then centrifuged at $2500 \mathrm{rpm}$ for $5 \mathrm{~min}$. The supernatant were decanted and the precipitates completely dissolved in 10 $\mathrm{mL} 20 \% \mathrm{H}_{2} \mathrm{SO}_{4}$. The total filtrates resulting from digestion of $2 \mathrm{~g}$ of each of the samples were made up to $200 \mathrm{~mL}$. Aliquots of $125 \mathrm{~mL}$ of the filtrate was heated until near boiling and then titrated against $0.05 \mathrm{M}$ standardized $\mathrm{KMnO}_{4}$ solutions to a pink colour which persisted for 30 sec. The oxalate contents of each sample were calculated (Munro and Bassiro, 2000).

\section{Phytate determination}

The phytate of each of the samples was determined through phytic acid determination using the procedure described by Lucas and Markaka, (1975). This entails the weighing of $2 \mathrm{~g}$ of each sample into $250 \mathrm{~mL}$ conical flask. $100 \mathrm{~mL}$ of $2 \%$ conc $\mathrm{HCl}$ was used to soak the samples in the conical flask for $3 \mathrm{~h}$ and then filtered through a double layer filter paper $50 \mathrm{~mL}$ of each of the sample filtrate were placed in a $250 \mathrm{~mL}$ beaker and $107 \mathrm{~mL}$ of distilled water added to give/ improve proper acidity. $10 \mathrm{~mL}$ of $0.3 \%$ ammonium thiocyanate solution was added to each sample solution as indicator and titrated with standard iron chloride solution which contained $0.00195 \mathrm{~g}$ iron $/ \mathrm{mL}$ and the end point was signified by brownish-yellow colouration that persisted for $5 \mathrm{~min}$. The percentage phytic acid was calculated (Russel, 1980).

\section{Trypsin inhibitor determination}

One gram of each sample A and B were dispersed in 50 $\mathrm{mL}$ of $0.5 \mathrm{~m} \mathrm{NaCl}$ solution. The mixture was stirred for 30 minutes at room temperature and centrifuged at 1500 $\mathrm{rpm}$ for $5 \mathrm{~min}$. The supernatants were filtered and the filtrates used for the assay. Two $\mathrm{mL}$ of the standard trypsin solution was added to $10 \mathrm{~mL}$ of the substrate of each sample. The absorbance of the mixture was taken at $410 \mathrm{~nm}$ using $10 \mathrm{~mL}$ of the same substrate as blank (Prokopet and Unlenbruck, 2002). Alkaloid determinaton: $5 \mathrm{~g}$ of each of the samples were dispersed into $50 \mathrm{~mL}$ of $10 \%$ acetic acid in ethanol, the mixture were shaken and allowed to stand for $4 \mathrm{~h}$ before filtration. The filtrate was evaporated to one quarter of the original volume. 
80 Afr. J. Food Sci. Technol.

Table 1. Phytochemical composition of methanol extract of Citrulus lanatus (Watermelon) seed extract

\begin{tabular}{|c|c|c|}
\hline Phytochemical Composition & $\begin{array}{l}\text { Citrulus lanatus (Watermelon) seed } \\
\text { (mg/100g) }\end{array}$ & $\begin{array}{l}\text { Cocos nucifera (coconut palm) } \\
\text { stem bark (mg/100g) }\end{array}$ \\
\hline Saponins & $1.553 \pm 0.0071$ & $0.23 \pm 0.04$ \\
\hline Tannins & $0.536 \pm 0.0057$ & $6.73 \pm 0.03$ \\
\hline Alkaloids & $33.795 \pm 0.035$ & $3.42 \pm 0.03$ \\
\hline Flavonoids & $2.310 \pm 0.014$ & $3.59 \pm 0.01$ \\
\hline Phenol & $1.371 \pm 0.042$ & $0.21 \pm 0.01$ \\
\hline Cyanogenic glycoside & $0.003 \pm 0.00$ & $0.002 \pm 0.00$ \\
\hline
\end{tabular}

Data represented in Mean \pm SEM

Table 2. Proximate composition of methanol extract of Citrulus lanatus (Watermelon) seed extract

\begin{tabular}{|c|c|c|}
\hline Proximate Compounds & $\begin{array}{l}\text { Citrulus lanatus (Watermelon) seed } \\
(\%)\end{array}$ & $\begin{array}{l}\text { Cocos nucifera (coconut palm) } \\
\text { stem bark (\%) }\end{array}$ \\
\hline Protein & $27.535 \pm 0.064$ & $1.84 \pm 0.00$ \\
\hline Ash & $4.138 \pm 0.015$ & $3.12 \pm 0.00$ \\
\hline Fats & $48.06 \pm 0.127$ & $7.12 \pm 0.00$ \\
\hline Fibre & $3.932 \pm 0.078$ & $1.64 \pm 0.00$ \\
\hline Moisture & $6.933 \pm 0.076$ & $12.25 \pm 0.01$ \\
\hline Carbohydrate & $9.407 \pm 0.203$ & $74.04 \pm 0.04$ \\
\hline
\end{tabular}

Data represented in Mean \pm SEM

Concentrated $\mathrm{NH} 4 \mathrm{OH}$ was added to each of the samples dropwise to precipitate the alkaloid. The precipitate were filtered off with weighed filter paper and washed with $1 \%$ $\mathrm{NH} 4 \mathrm{OH}$ solution. The precipitates in each case were dried at $60^{\circ} \mathrm{C}$ for $30 \mathrm{~min}$ and reweighed (Griffiths, 2000).

\section{Hemaglutinin determination}

Two gram of each of the sample was added $20 \mathrm{~mL}$ of $0.9 \% \mathrm{NaCl}$ and suspension shaken vigorously for $1 \mathrm{~min}$. The supernatants were left to stand for $1 \mathrm{~h}$ the samples were then centrifuged at $2000 \mathrm{rpm}$ for $10 \mathrm{~min}$ and the suspension filtered. The supernatants in each were collected and used as crude agglutinating extract.

\section{Statistical analysis}

Three analytical determinations were carried out on each independent replication for every parameter. Three independent replicates $(n=3)$ were obtained from each treatment and the results presented in tables and are reported as means \pm standard error of mean (SEM). Data were analysed by t-test $(P<0.05)$.

\section{RESULTS}

Table 1 summarizes the quantitative determination of phytochemical constituents of Citrulus lanatus seed and Cocos nucifera stem bark. The result reveals that both plants contain substantial amount of saponnins, tannins, flavonoids and phenol. The concentration of alkaloids present in the $C$. lanatus seed were significantly $(p<0.0 .05)$ higher compared with the level observed in $C$. nucifera stem bark. The value of cyanogenic glycosides was very trace on both plants.

The result of proximate analysis of the seed of $C$. lanatus and $C$. nucifera stem bark were presented in table 2 . There was generally low percentage proximate fractions of $C$. lanatus seeds in terms ash and fibre and low percentage fractions of protein, ash, fats and fibre weer observed in the $C$. nucifera stem bark. Protein and fats composition of $C$. lanatus were observed to be significantly $(P<0.05)$ higher compared with the compositions present in $C$. nucifera while the percentage moisture and carbohydrate composition in $C$. nucifera were revealed to be significantly $(P<0.05)$ higher compared with the concentration of these proximate compounds in C. lanatus (table 2 ).

The mineral and nutrient contents of both plants are shown in table 3 . Iron was the most abundant micro element present ranging from $4.089 \mu \mathrm{g} / \mathrm{g}$ in C. lanatus seed to $3.66 \mu \mathrm{g} / \mathrm{g}$ in C. nucifera stem bark. This is followed by zinc, which was present from $1.082 \mu \mathrm{g} / \mathrm{g}$ in $C$. lanatus seed to $3.50 \mu \mathrm{g} / \mathrm{g}$ in $C$. nucifera stem bark. The values of magnesium were very trace on both plants. Results of analysis of $C$. lanatus seed and $C$. nucifera stem bark showed that the plants are rich in some vitamins such as vitamin $A, E$ and $C$ which were observed to be abundant in both plants while low concentration of thiamine, riboflavin and niacin were observed in both plants.

The anti-nutrient analysis of $C$. lanatus seed and $C$. nucifera stem bark revealed low level of phytate, oxalate, hemaglutinin and trypsin inhibitor ranging from 0.677 $\mathrm{mg} / 100 \mathrm{~g}$ to $2.370 \mathrm{mg} / 100 \mathrm{~g}, 0.082 \mathrm{mg} / 100 \mathrm{~g}$ to 0.97 
Table 3. Nutrients composition of methanol extract of Citrulus lanatus (Watermelon) seed extract

\begin{tabular}{lll}
\hline \multicolumn{1}{c}{ Nutrient compounds } & Citrulus lanatus (Watermelon) seed & $\begin{array}{l}\text { Cocos nucifera (coconut palm) } \\
\text { stem bark }\end{array}$ \\
\hline Zinc $(\boldsymbol{\mu g} / \mathbf{g})$ & $1.082 \pm 0.0085$ & $3.50 \pm 0.01$ \\
Iron $(\boldsymbol{\mu g} / \mathbf{g})$ & $4.089 \pm 0.037$ & $3.66 \pm 0.00$ \\
Magnesium (\%) & $0.023 \pm 0.016$ & $0.18 \pm 0.00$ \\
Vitamin A (mg/100g) & $34.21 \pm 0.156$ & $49.50 \pm 0.01$ \\
Vitamin E (mg/100g) & $20.62 \pm 0.212$ & $30.45 \pm 0.04$ \\
Vitamin C (mg/100g) & $22.095 \pm 0.092$ & $20.90 \pm 0.09$ \\
Thiamine (mg/100g) & $0.115 \pm 0.0071$ & $0.09 \pm 0.14$ \\
Riboflavin (mg/100g) & $0.135 \pm 0.035$ & $0.64 \pm 0.04$ \\
Niacin $(\mathbf{m g / 1 0 0 g )}$ & $1.332 \pm 0.013$ & $0.65 \pm 0.06$ \\
\hline
\end{tabular}

Data represented in Mean \pm SEM

Table 4. Anti-nutrients composition of methanol extract of Citrulus lanatus (Watermelon) seed extract

\begin{tabular}{lll}
\hline \multicolumn{1}{c}{ Anti-nutrient Compounds } & Citrulus lanatus (Watermelon) seed & $\begin{array}{l}\text { Cocos } \begin{array}{c}\text { nucifera } \\
\text { palm) stem bark }\end{array} \\
\text { (coconut }\end{array}$ \\
\hline Phytate $(\mathbf{m g / 1 0 0 g )}$ & $0.677 \pm 0.0057$ & $2.37 \pm 0.00$ \\
Oxalate (mg/100g) & $0.082 \pm 0.0042$ & $0.97 \pm 0.00$ \\
Hemaglutin (\%) & $0.549 \pm 0.0085$ & $0.69 \pm 0.01$ \\
Trypsin inhibitor (mg/100g) & $0.456 \pm 0.0085$ & $0.55 \pm 0.00$ \\
\hline
\end{tabular}

Data represented in Mean \pm SEM

$\mathrm{mg} / 100 \mathrm{~g}, 0.549 \%$ to $0.690 \%$ and $0.456 \mathrm{mg} / 100 \mathrm{~g}$ to $0.550 \mathrm{mg} / 100 \mathrm{~g}$ respectively (table 4 ).

\section{DISCUSSION}

The bioactive compounds observed to be present in both plants are known to exhibit medicinal as well as physiological activity (Sofowora, 1993; Adeniyi et al., 2012). The presence of alkaloid showed that both plants can be used as basic medicinal agents for their analgesic, antispasmodic and bactericidal effects (Stray, 1998; Okwu and Okwu, 2004). Flavonoids are potent water soluble antioxidants and free radical scavengers which prevent oxidative cell damage, have strong anticancer activity (Salah et al., 1995; Del-Rio et al., 1997). Flavonoids are also known to have antiinflammatory, anti-allergic and anti-viral properties (Adeniyi et al., 2012). They can lower the risk of arthritis, osteoporosis, allergies and viral disease caused by herpes simplex virus, parainfluenza virus and adenovirus (Okwu, 2004; Adeniyi et al., 2012). Flavonoids can also prevent atherosclerosis, which is a disease characterized by the deposition of fats inside the arterial wall. Such deposition narrows the arteries and thereby, hinders blood flow to the vital organs of our body, like heart and brain. So, this disease increases the risk of heart attack and stroke. Flavonoids, by preventing atherosclerosis, lower the risk of coronary heart diseases (Adeniyi et al., 2012). High content of tannin decrease protein quality by decreasing digestibility and causes damage to the intending track (Sam et al., 2012). Dutta, (2003) reported that, tannins are responsible for the flavour in tea and it use in the treatment of skin eruption and for other medicinal purposes due to their astringent properties. The presence of saponin is an indication that the plants possess the property of precipitating and coagulating red blood cells. Some of the characteristics include formation of foams in aqueous solutions, hemolytic activity, cholesterol binding properties and bitterness (Sodipo et al., 2000; Okwu, 2004; Adeniyi et al., 2012). The level of cyanogenic glycoside was found to be in trace amount. The knowledge of the cyanogenic glycoside content of food is vital because cyanide being an effective cytochrome oxidase inhibitor interfers with aerobic respiratory system (Aina et al., 2012). Minerals are important for vital body functions such as acid, base and water balance. Iron is an important constituent of hemoglobin (Onwordi et al., 2009). Therefore, this is probably why some people use these plants to build-up hemoglobin, especially when they are recovering from sickness (Adeniyi et al., 2012). Zinc is needed in the body to help the pancreas produce insulin, to allow insulin to work more effectively and to protect insulin receptors on cells Okaka and Okaka, 2001). Therefore the presence of zinc in the studied plants could mean that the plants can play valuable roles in the management of diabetes, which results from insulin malfunction. Magnesium ions are known hormone activators in type 2 diabetes, their presence in the studied plants can be beneficial in managing this disease. These plants are good source of vitamin C (ascorbic acids), vitamin $A$ and vitamin $E$ (Table 4). Natural ascorbic acid is vital for body performance (Okwu, 2004). Lack of ascorbic acid impairs the normal formation of intercellular substances throughout the body, including collagen, bone matrix and 
tooth dentine. The pathological change resulting from this defect is the weakening of the endothelial wall of the capillaries due to reduction in the amount of intercellular substances (Adeniyi et al., 2012). Therefore, the clinical manifestations of scurvy hemorrhage from mucous membrane of the mouth and gastrointestinal tract, anemia, pains in the joints can be related to the association of ascorbic acid and normal connective tissue metabolism (Hunt et al., 1980; Okwu, 2004). This function of ascorbic acid also accounts for the requirement for normal wound healing (Adeniyi et al., 2012). As a result of the availability of ascorbic acid in both plants, they can be used in herbal medicine for the management of oxidative stress and prevent oxidative damage of the organs and tissues since vitamin A, C and E serve as antioxidants that can scavenge free radicals generated in the body. Phytic acid, a hexaphosphate derivative of inositol is an important, storage form of phosphorus in plant. Phytate is an anti-nutrient that interferes with the absorption of minerals from the diet. It causes calcium and zinc deficiency in man when in excess, the deficiency of these minerals results in Oteo-malacia, anaemia and rickets (Sam et al., 2012). The level of phytate in C.

lanatus seeds and C. nucifera stem bark were observed to be 0.677 and $2.37 \mathrm{mg} / 100 \mathrm{~g}$. The low level of phytic acid could be attributed to the presence of an enzyme phytase which degrade phytic acid in plants (Aina et al., 2012). Oxalates are regarded as undesirable constituents of the diets, reducing assimilation of calcium, favoring the formulation of renal calcium (Fagboya, 1990). The low anti-nutrient content of the seed of Citrulus lanatus and Cocos nucifera stem bark is an indication of good diet and medicinal source.

\section{CONCLUSION}

This study has shown that C. lanatus seed and C. nucifera stem bark are good source of phytochemicals that are biologically important, thus they can be potential sources of useful herbs in the management of some ailments. The trace amounts of anti-nutrient compounds indicate that the plants can serve as good dietary supplement. Also, these plants contain appreciable level of proximate compounds, vitamins and minerals that are readily available; they could be consumed to supplement the scarce or non-available sources of nutrients.

\section{REFERENCE}

Adeniyi SA, Orjiekwe CL, Ehiagbonare JE, Arimah BD(2012). Evaluation of chemical composition of the leaves of Ocimum gratissium and Vernonia amygdalina. Int. J. Biol. Chem. Sci., 6(3): $1316-1323$

Aina VO, Sambo B, Zakari A, Haruna MS, Umar H, Akinboboye RM, Mohammed $A(2012)$. Determination of Nutritional and Anti-Nutrient Content of Vitis vinifera (Grapes) Grown in Bomo (Area C) Zaria,

Nigeria. Advance Journal of Food Science and Technology, 4(6): 445448.
AOAC. (1990). Offical Methods of Analysis. Association of official Chemists. 15th Ed. Washington DC. Association of official and Analytical Chemists: Pp: 234.

Barakat MZ, Shehab SK, Darwish N, Zahermy El(1973). Determination of ascorbic acid from plants. Analyst Biochem., 53: 225-245.

Boham AB, Kocipai AC(1994). Flavonoid and condensed tannins from Leaves of Hawaiian vaccininum vaticulum and vicalycinium. Pacific Sci., 48: 458-463

Collins JK, Wu G, Perkins-veazie P, Spears K(2007). Watermelon consumption increases plasma arginine concentration in adult. Nutrition. 23: 261-266

Del-Rio A, Obdululio BG, Casfillo J, Marin FG, Ortuno A(1997). Uses and Properties of citrus flavonoids. J. Agric Food Chem., 45: 45054515.

Dutta AC(2003). Botany for Degree students (6th edn). Oxford University press. Pp: $140-143$

Fagboya OO(1990). The interaction between oxalate acid and divalent ions, $\mathrm{Mg}+, \mathrm{Ca} 2+, \mathrm{Zn} 2+$ in aqueous medium. Food Chemistry, 38: 179-189.

Griffiths DO(2000). The inhibition of enzymes by extract of field beans (Vicia faba). J. Sci. Food Agric., 30: 458-462.

Hunt S, Groff IL, Holbrook J(1980). Nutrition, Principles and Chemical Practice. John Wiley and Sons: New York; Pp: 49-52; 459- 462.

Lucas GM, Markakas P(1975). Phytic acid and other phosphorus compounds of bean (Phaseolus vulgaris). J. Agric. Edu. Chem., 23: 13-15.

Mandel H, Levy $\mathrm{N}$, Korman $\mathrm{SH}(2005)$. Elevated plasma citrulline and arginine due to composition of citrulus vulgaris (watermelon). Berichte der Doutschen Chemischen Gesellschaft. 28(4): 467-472.

Munro O Basir, O(1969). Oxalate in Nigeria vegetables. W. Afr. J. Biol. Appl. Chem., 12: 14-18.

Obadoni BO, Ochuko PO(2001). Phytochemical studies and Comparative efficacy of the crude extracts of some homeostatic plants in Edo and Delta States of Nigeria. Global J. Pure Appl. Sci., 8: 203-208.

Okaka JC, Okaka ANO(2001). Food composition, spoilage and shelf life extension. Ocjarco Academic Publishers, Enugu, Nig. Pp. 54, 56.

Okwu DE(2004). Phytochemicals and vitamin content of indigenous spices of Southeastern Nigeria. J. Sustain. Agric. Environ., 6(1): 3037.

Okwu DE, Josiah C(2006). Evaluation of the chemical composition of two Nigerian medicinal plants. African Journal of Biotechnology, 5 (4): 357-361

Okwu DE, Okwu ME(2004). Chemical composition of Spondias mombin linn plant parts. J. Sustain Agric. Environ., 6(2): 140-147.

Omoboyowa DA, Nwodo OFC, Joshua PE(2013). Anti-diarrhoeal activity of chloroform-ethanol extracts of cashew (Anacardium occidentale) kernel. Journal of Natural Products, 6: 109-117.

Onwordi CT, Ogungbade AM, Wusu AD(2009). The proximate and mineral composition of three leafy vegetables commonly consumed in Lagos, Nigeria. African J. Pure and Applied Chem., 3(6): 102-107.

Onwuka G(2005). Food Analysis and Instrumentation. Naphohla Prints. 3rd Edn., A Division of HG Support Nigeria Ltd., Pp: 133-161.

Prokopet G, Unlenbruck KW(2002). Protectine eine nen kalsse antikowperahlich verbindungen dish. Ges. Heit., 23: 318.

Railes $R(1992)$. Effect of chromium chloride supplementation on glucose tolerance and serum lipids including HDL of adult men. Am. J. Clini. Nutr., 34: 697-700.

Ravi $R(2009)$. Rise in coconut yield, Farming area put India on top. www.financialexpress.com 15th August, 2014.

Riaz A, Khan RA, Ahmed S, Afroz S(2010): Assessment of acute toxicity and reproduction capability of herbal combination. Pakistan J. of Pharmaceutical Sciences. 23: 291-294.

Russel HS(1980). India-New England Before the May Flower. University Press of New England Handover.

Salah N, Miller NJ, Pagange G, Tijburg L, Bolwell GP, Rice E, Evans C(1995). Polphenolic flavonoids as scavenger of aqueous phase radicals as chain breaking antioxidant. Arch. Biochem. Broph., 2: 339-346. 
Sam SM, Udosen IR, Mensah SI(2012). Determination of proximate, minerals, vitamin and anti-nutrients composition of solanum verbascifolium linn. International Journal of Advancements in Research and Technology, 1(2): 1-10

Sarian SB(2010). New coconut yield high. The Manila Bulletin. www.mb.com.ph 18th September, 2014.

Shahidi F, Chavan UD, Bal AK, Mckenzie DB(1999). Chemical Composition of Beach pea (Lathyrus maritimus $L$ ) plant parts. Food Chem., 64: 39-44.

Sodipo OA, Akiniyi JA, Ogunbamosu JU(2000). Studies on certain Characteristics of extracts of bark of Pansinystalia macruceras (Kschemp) pierre Exbeille. Global J. Pure Appl. Sci. 6: 83-87.

Sofowora LA(1993). Medicinal Plants and Traditional Medicine in
Africa. Spectrum Books Ltd: Ibadan; Pp: 55-71.

Stray F(1998). The Natural Guide to Medicinal Herbs and Plants. Tiger Books International: London; 12-16.

Van-Burden TP, Robinson WC(1981). Formation of complexes between protein and tannin acid. J. Agric Food Chem., 1: 77-82.

Weigert $P(1991)$. Metal loads of food of vegetable origin including mushrooms. In Metals and Their Compounds in the Environment: Occurrence, Analysis and Biological Relevance. Merian E (ed). Weinheim, VCH; Pp: 458-468. 